\title{
Capability and Practice in Procurement Collaboration: A Vendor's Perspective of Benefits
}

\author{
Damien Power \\ Department of Management and Marketing, Faculty of Economics and Commerce \\ University of Melbourne, Parkville, Victoria, 3010, Australia \\ Email: damien@unimelb.edu.au
}

\begin{abstract}
This paper is based on a study of 105 Australian manufacturing companies focusing on their relationships as vendors with customers. In particular, the focus of the paper was on determining the extent to which collaboration through both Internet based technological capability and collaborative practices involving partnering with customers influenced three separate aspects of firm performance: operational, quality and financial. The results show that vendors perceive collaboration with customers to directly influence operational performance and quality performance. They do not see any direct link with financial outcomes. There is evidence, however, suggesting that financial performance is influenced by operational and quality performance. The findings indicate that vendors may find it difficult to see the real benefits of collaboration due to the nature of the relationship with customers. The results are explained in terms of both transaction cost theory and the knowledge based view of the firm.
\end{abstract}

Keywords: Information Technology, Supply Chain, Internet, Collaboration.

\section{Introduction}

Collaboration between customers and suppliers is now generally accepted to offer many potential benefits for organizations seeking to better manage supply chain activity (Vereecke and Muylle, 2006). Established theory can be used to explain this potential, and to identify a number of factors that may motivate managers to pursue collaboration with trading partners (Barringer and Harrison, 2000). Transaction cost economics emphasizes the importance of developing appropriate governance mechanisms for the regulation of trading partner interactions (Williamson, 1975; Williamson, 1985). The effectiveness of the mechanism can be assessed on the basis of the sum of both production and transaction costs, with the assumption being that the most efficient form of governance will prevail. One way firms may seek to minimize the sum of these costs is through collaborative arrangements (Williamson, 1991; Jarillo, 1988). On the other hand, a firm may be motivated to pursue collaborative arrangements due to a dependency on a particular resource(s) (Thorelli, 1986), coupled with the realization that it can only be accessed through interacting with the external environment (Scott, 1987). Resource dependence theory would therefore explain collaboration in these terms, with the relationship between trading partners being governed by the perceived need of one firm to control another that has the resource(s) (Thorelli, 1986), or conversely by development of a partnership in order to gain access to the resource(s) (Oliver, 1990; Fisher, 1996). Alternatively, firms may pursue collaboration because it creates strategic advantages enabling revenue and/or profit growth through increasing market power (Harbison and Pekar, 1998), access to strategic knowledge (Grant and Baden- 
Fuller, 1995; Grant, 1997; Grant and Baden-Fuller, 2004), or operational efficiencies through sharing risk and pursuing scale economies (Powell, 1990). Whatever the motivation for collaboration, it is important to bear in mind that in any system whereby multiple partners pursue joint strategies, that it is unlikely that all will share equally in the benefits that accrue (Stephen and Coote, 2005; van Donk and van der Vaart, 2005). Further, the conditions under which firms can expect to realize these benefits are at best poorly understood, with some empirical studies indicating that outcomes appear to be often based in the context of the industry or the dispositions of the trading partners themselves (Wuyts and Geyskens, 2005). This study examines how vendors perceive they benefit from collaboration with customers both in terms of capability (internet based technological links), and practice (actual collaborative practice).

\section{Literature Review and Hypotheses}

The relationship between business benefits and collaborative trading partner relationships has been an important research theme in the supply chain management literature. In fact, when Forrester first modeled the dynamics of supply chain systems an important implication was the potential role collaboration could play in mitigating the problems he identified (Vickery et al., 2003; Forrester, 1958; Forrester, 1961). The three causes Forrester isolated - Structure (the way the supply chain is constructed), Amplitude (over reaction by decision makers) and Delays (separation between cause and effect in both time and space) - were identified as being linked to disconnects between decision makers within the system. Subsequent simulation studies have also shown that closer collaboration between trading partners, coupled with integration of systems and processes, can substantially reduce demand amplification and inventory imbalances (Lee and Clark, 1999; Lee et al., 1997a; Lee et al., 1997b; Lee and Whang, 2000). The problems identified in the nature of supply chain dynamics have become known as the "bullwhip effect" (Lee et al., 1997a), with there now being a substantial body of literature confirming the existence of the phenomenon (Chen et al., 2000a; Chen et al., 2000b; Dejonckheere et al., 2003; Disney and Towill, 2003; Metters, 1997). It is also apparent, however, that although this phenomenon is well documented, substantial debate still continues as to whether the source of the problem lies in the nature of the supply chain (Djonckheere et al., 2003; Djonckheere et al., 2004; Chen et al., 2000b; Lee et al., 1997b) or the mind of the decision maker (Sterman, 1989). Whatever the cause, the understanding of this problem has been instrumental in providing impetus for the collaborative form of trading partner relationship as being preferable to the traditional "arms-length" or market based model in the supply chain management literature (Lee and Billington, 1995; Fernie, 1995; Dyer and Singh, 1998; Dyer et al., 1998). The problem with this paradigm, however, is that it is predicated on some fundamental assumptions regarding trust, shared benefits and a system wide perspective of performance that are hard to reconcile with the competitive dynamics of a free market model (Williamson, 1975; Monczka et al., 1998; Landry, 1998; Kwon and Suh, 2004; Kleist, 2004; Hart and Saunders, 1997; Gulati, 1995). In other words, although it is commonly accepted that the dynamics of supply chain systems can significantly limit the ability of individual players to be competitive, the fragmentation of interests between trading partners make it difficult to commit to the collaborative model (Akkermans et al., 2004; Johnston et al., 2004; Mouritsen and Thrane, 2006). Although it may be better for the system for there to be greater levels of collaboration and integration between trading partners, the benefits for individuals within the system may not be readily identified. This problem appears to be further exacerbated by the pressures for change within the firm resulting from such collaboration (Power and Singh, 2007). In this sense, the question becomes not one of whether or not to collaborate, but more whether collaboration is good for the individual firm, or indeed which collaborator(s) will benefit most.

Research into the benefits of collaboration between supply chain trading partners highlights the nature of the problem of who benefits and why. The case for caution in terms of universally applying the collaborative model is one that recurs through both early and more recent studies (New and Burnes, 1998; Vereecke and Muylle, 2006; Kersten et al., 2004; Stuart, 1997). The notion that collaboration results in "win-win" outcomes in particular has 
been questioned (New and Burnes, 1998), while the potential for broader adoption has by others been said to have been over-estimated (Zajac and Olsen, 1993). A recent European study found evidence for a relationship between collaboration and higher levels of performance, but no clear link suggesting that collaboration was the cause (Vereecke and Muylle, 2006). Further, in an international supply chain context it has been shown that cultural, infrastructure and geographical issues serve to modify the ability for trading partners to realize the potential of collaboration (Dyer et al., 1998; Dyer and Singh, 1998; Fernie, 1995).

In terms of organizational theory these problems inherent in being able to explain why such relationships can produce different outcomes for different players have been explained as being a function of conflicting theoretical perspectives. For example, two theories that are particularly relevant to the collaboration debate are Transaction Cost Economics (TCE) and the Knowledge Based View (KBV) of the firm. One takes the perspective that the economic cost of collaboration will increase with higher levels of collaboration due to managers being bounded in their ability to select "trustworthy" suppliers, and the subsequent propensity to become the victim of opportunistic behavior (Williamson, 1975; Williamson, 1991). The Knowledge Based view, on the other hand, sees collaboration as fundamental to enabling knowledge transfer (Grant and BadenFuller, 1995; Grant, 1997; Grant and Baden-Fuller, 2004), and thus the mitigation of the sub-optimal operation of supply chain systems identified by Forrester and others (Forrester, 1961; Forrester, 1958; Lee et al., 1997a; Lee et al., 1997b). The polarization of these two viewpoints creates a dilemma for research in this area, as either can be used to make a convincing argument for or against collaboration, or conversely can be used to explain why they appear to work or why they don't, although some recent work in the field of economics has attempted to begin to reconcile this apparent conflict (Heiman and Nickerson, 2002; Heiman and Nickerson, 2004).

The supply chain literature provides evidence supporting these conflicting theoretical explanations, particularly in studies focusing on why collaboration does or does not work. Typical themes to have emerged include: difficulty in letting go of a traditional "arms-length" mentality implying a lack of trust and fears of opportunism (Spekman and Carraway, 2006); pricing not being recognized for its potential to provide an optimized supply chain wide outcome (Voeth and Herbst, 2006), implying both fears regarding knowledge transfer and a firm based rather than supply chain system view of the relationship; over optimistic expectations from the relationship, often driven by the buyer over-selling the concept to the supplier, coupled with a reluctance to share information on the part of the buyer (Stuart, 1997); a lack of awareness of the existence of structural and infra-structural constraints in the supply chain (Simatupang et al., 2004) implying a reluctance on the part of both parties to take an holistic view and to share this view; the identification of trust as being the key determinant of success for vendor managed inventory (VMI) programs (Fearne et al., 2006) implying that if managers can identify "trustworthy" vendors (overcome "bounded rationality") they gain access to strategic information that can benefit both parties; and difficulties observed in linking external collaboration with internal functional collaboration (Holweg et al., 2005) implying that transfer of knowledge cannot be effectively enabled between trading partners if it is not effectively practiced within the firm.

Despite this apparently hazy picture of potential benefits and partially realized outcomes, there have been some recent studies providing evidence that benefits from collaboration are related to better management of information flows. In particular, a study in the North American food and packaged goods industry found both manufacturers and retailers benefited from collaboration through the integration of planning information to enable VMI (Kulp et al., 2004). Of most interest was the finding that knowledge transfer through collaborative practice (i.e. real working partnerships) was found to be the source of the majority of these benefits, as distinct from information sharing (being connected through various technological means) or the capability for knowledge transfer. In terms of the two theories discussed above, these findings resonate as they provide both an explanation for the lowering of transaction costs through partnering with trusted allies, and differentiate between the capability to share knowledge (being technologically connected) and the practice of knowledge sharing through strategic partnering. Other recent studies 
provide indirect support for these findings. A German study from the automotive industry found that despite a high degree of capability to connect between suppliers and OEM's, non-technological factors such as fear of loss of competitive knowledge arbitrage (particularly in the case of the supplier) significantly impeded successful electronic collaboration (Kersten et al., 2004). Another North American study in the automotive industry (taking a sample of first tier suppliers) also found that use of integrative information technologies within the supply chain (capability) had no direct impact on firm performance (Vickery et al., 2003). However, use of such technologies was found to have an indirect effect when mediated by supply chain integration practice (defined as partnering with suppliers and customers). Another study in the fast moving consumer goods (FMCG) sector in the UK has found that many suppliers to major supermarket chains are skeptical and apathetic about programs such as "efficient consumer response" (Corsten and Kumar, 2003). At the same time, however, this study also found that there was significant evidence suggesting that these same suppliers did in fact benefit from these programs, the problem being that levels of trust were very low between the parties, and as such the benefits were not apparent to the vendor. In other words, the quality of the relationship (collaborative practice) was a powerful enough factor to cloud vendors' perceptions of the value of collaboration.

In all cases these latter studies provide evidence suggesting that the benefits of collaboration are at the same time elusive and attractive. They also show that they come at a cost, and that the trade-off between cost and benefit is possibly explained through the interaction of these two theoretical perspectives seeking to make sense of the collaboration dilemma. The benefit of greater knowledge sharing carries the risk of transparency and potential for opportunistic behavior. The risk associated with not sharing knowledge is one of economic and technological isolation in a world where trading networks are becoming more commonplace. The relationship between costs of coordination and the costs relating to risk of opportunism can be mitigated by partnering with those you can trust, but trust is a rare commodity in competitive market based economies.
The net result is that collaborative practice, and the benefits that accrue, is an important area for continuing research. In particular, it is important to look at the issues from the perspective of different players in the supply chain as a firm's perspective on the benefits of collaboration can be expected to differ based on who that firm collaborates with. For example, in simple terms it is likely that the perceived value of collaboration will differ based on the nature of the trading relationship - whether you are dealing with customers or suppliers. Generally the nature of the relationship with customers can be expected to be one where the focus on providing service acts as a form of governance. As such, it could be that many vendors are involved in collaboration because they believe it will help grow their revenues, create a stronger competitive position, or because their customers have mandated it. It is in this context that this paper finds its focus by seeking to study the perceptions of vendors of the benefits they accrue from collaboration with customers. In other words, it is assumed in many studies that vendors become involved in collaborative arrangements with customers expecting there to be a benefit for them, either direct or indirect. As the preceding discussion has shown, these benefits may or may not be realized. Further, the nature of the relationship with the customer may be such that potential benefits may not be the object, rather that collaboration is seen to be governed by the need vendors have to be connected to customers.

The hypotheses below provide the framework around which this study has been conducted. The two constructs of collaboration that are used are drawn from a synthesis of the concepts derived from the studies discussed above (Kersten et al., 2004; Kulp et al., 2004; Vickery et al., 2003). These two constructs are described as "Internet based technological capability" (capability) and "collaborative practice with customers" (practice). Each hypothesis proposes a positive link between three separate performance constructs - operational performance, quality performance and financial performance and either capability or practice.

\section{Hypotheses}

H1a: Vendors' operational performance will benefit from utilizing an Internet based technological capability 
H1b: Vendors' operational performance will benefit from utilizing collaborative practices with customers

H2a: Vendors' quality performance will benefit from utilizing an Internet based technological capability

H2b: Vendors' quality performance will benefit from utilizing collaborative practices with customers

H3a: Vendors' financial performance will benefit from utilizing an Internet based technological capability

H3b: Vendors' financial performance will benefit from utilizing collaborative practices with customers

The purpose is to test whether vendors perceive there to be benefits for them deriving from collaborative capability (technology based information sharing) and collaborative practice (real working partnerships).

\section{Method}

\subsection{Data Collection}

A survey was conducted within the membership of the Chartered Institute of Purchasing and Supply Australia (CIPSA). This organization is the major peak body representing operations and supply professionals in Australia. 1825 members of this organization were sent surveys with 310 usable responses being received (response rate of $17 \%$ ). The membership of this body covers a range of sectors including health care, manufacturing, government and other service based sectors, the focus of this study being on the 105 responses received from the manufacturing sector. Confidence in the sample being representative of the broader manufacturing sector within Australia was established by comparing the profile of respondents (based on company size) with that of the results published by the Australian Bureau of Statistics. No significant differences were found on this dimension. Confidence in the sample being representative of the full membership of CIPSA was gained by comparing early respondents with those who responded after the receipt of a follow up letter. Again there was no significant difference recorded on the dimension of company size.

\subsection{Development of Constructs}

The constructs used in this study were developed from a synthesis of the themes identified in previous studies and discussed in the literature above. These constructs were operationalized through a series of interviews with procurement and supply chain management professionals, and further refined with academic peer review. Face validity of the constructs was established through this process.

Figure 1: Diagrammatic representation of hypotheses

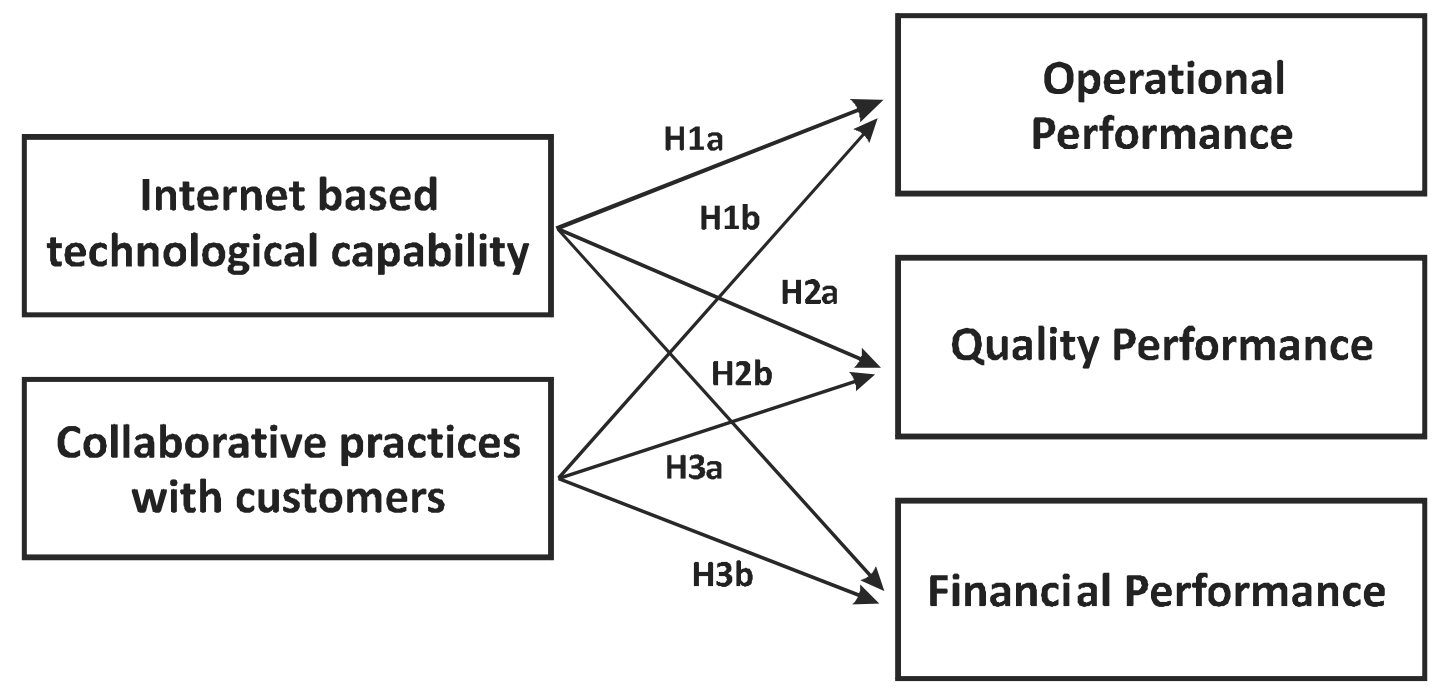


Table 1. Rotated Component Matrix - Capability and Practice Constructs

\begin{tabular}{|c|c|c|}
\hline & $\begin{array}{c}\text { Factor } 1: \\
\text { Internet based } \\
\text { technological capability } \\
(\text { Alpha }=0.800)\end{array}$ & $\begin{array}{c}\text { Factor 2: } \\
\text { Collaborative practice } \\
\text { with customers } \\
\text { (Alpha }=0.762 \text { ) }\end{array}$ \\
\hline Our organization is using XML/EDI applications for web based document transfer & .798 & .147 \\
\hline Our organization is using XML applications for interfacing with major trading partners & .750 & .035 \\
\hline Our organization is using Extranets for dealings with major trading partners & 690 & .195 \\
\hline Our organization is using web based catalogs for dealings with major trading partners & 630 & -.229 \\
\hline $\begin{array}{l}\text { Our organization is using the Internet for business to business transactions with many major } \\
\text { customers on a daily basis }\end{array}$ & .548 & .225 \\
\hline Our organization has access to trading partner forecasts & .003 & .796 \\
\hline $\begin{array}{l}\text { Our organization coordinates physical movement of goods and information flows with trading } \\
\text { partners }\end{array}$ & .196 & .775 \\
\hline Our organization has access to point of sale data & -.059 & .656 \\
\hline Our organization has cooperative trading partner agreements with customers & .217 & .594 \\
\hline
\end{tabular}

Table 2. Rotated Component Matrix - Operational, Financial and Customer Service Performance Constructs

\begin{tabular}{|l|c|c|c|}
\hline & $\begin{array}{c}\text { Factor 1: } \\
\text { Operational Performance } \\
\text { (Alpha = 0.838) }\end{array}$ & $\begin{array}{c}\text { Factor 2: } \\
\text { Financial Performance } \\
\text { (Alpha = 0.860) }\end{array}$ & $\begin{array}{c}\text { Factor 3: } \\
\text { Quality Performance } \\
\text { (Alpha = 0.731) }\end{array}$ \\
\hline Schedule accuracy & .821 & .242 & .041 \\
Transportation costs & .757 & .149 & .013 \\
Control of WIP inventory & .683 & .116 & .267 \\
Order backlog management & .663 & .267 & .124 \\
Control of finished goods inventory & .622 & -.030 & .393 \\
Net profit & .174 & .844 & .183 \\
Cash flow & .198 & .812 & .030 \\
Sales growth & .163 & .791 & .294 \\
Product quality & .007 & .039 & .832 \\
Service quality & .227 & .354 & .742 \\
Customer satisfaction & .304 & .224 & .627 \\
\hline
\end{tabular}

Exploratory factor analysis was used to determine the psychometric properties of the constructs, and to provide confidence in their validity and reliability. Tables 1 and 2 below show the results of this analysis with comparative factor loadings and Cronbach's alpha results for the five constructs of interest.

These results show that all constructs display characteristics consistent with meeting the requirements for both convergent and discriminant validity. The Cronbach's alpha results also provide evidence that each construct is a reliable scale. The loadings also indicate that construct validity is adequate, and this was further enhanced by the $\mathrm{KMO}$ and Bartlett's test results falling within acceptable ranges. Each construct was reduced to a single factor variable for use in the subsequent regression analysis.

\subsection{Data Analysis Method}

The method used to test each hypothesis was hierarchical regression. For each hypothesis the two constructs used as independent variables were the capability and practice constructs, with the dependent variables being operational, quality and 
financial performance in turn. In all three models company size was used as a control variable. The sequence of entry of independent variables was the same for all three models, being company size first, followed by Internet based technological capability and lastly collaborative practice with customers.

\section{Data Analysis and Findings}

H1a: Vendors' operational performance will benefit from utilizing an Internet based technological capability

H1b: Vendors' operational performance will benefit from utilizing collaborative practices with customers

Model 1 (see Table 3 below) was used to test these hypotheses. The results indicate that there is support for both hypotheses. The effect of utilizing an Internet based technological capability on operational performance was found to be weak though significant for the manufacturing vendors participating in the survey. A similar result was recorded for the use of collaborative practices with customers, and the model indicated that the combined effect of the two predictors was that they explained $9.6 \%$ of the variance in operational performance. As such, both $\mathrm{H} 1 \mathrm{a}$ and $\mathrm{H} 1 \mathrm{~b}$ are accepted.

H2a: Vendors' quality performance will benefit from utilizing an Internet based technological capability

H2b: Vendors' quality performance will benefit from utilizing collaborative practices with customers

Model 2 (see Table 4 below) was used to test these hypotheses. The results indicate that there is support for $\mathrm{H} 2 \mathrm{~b}$ only. No significant result was recorded in support of $\mathrm{H} 2 \mathrm{a}$, while for $\mathrm{H} 2 \mathrm{~b} 7.8 \%$ of the variance in quality performance was accounted for by use of

Table 3. Model 1 - Internet based technological capability and Collaborative practice with customers as predictors of Operational Performance (Control variable $=$ Company Size)

\begin{tabular}{|c|c|c|c|c|c|c|c|c|c|}
\hline \multicolumn{10}{|c|}{ Model Summary } \\
\hline \multirow[b]{2}{*}{ Model } & \multirow[b]{2}{*}{$\mathrm{R}$} & \multirow[b]{2}{*}{ R Square } & \multirow[b]{2}{*}{$\begin{array}{l}\text { Adjusted } \\
\text { R Square }\end{array}$} & \multirow[b]{2}{*}{$\begin{array}{l}\text { Std. Error of } \\
\text { the Estimate }\end{array}$} & \multicolumn{5}{|c|}{ Change Statistics } \\
\hline & & & & & $\begin{array}{l}\text { R Square } \\
\text { Change }\end{array}$ & F Change & df 1 & df2 & Sig. F Change \\
\hline 1 & $.126^{\mathrm{a}}$ & .016 & .006 & .99687879 & .016 & 1.652 & 1 & 103 & .202 \\
\hline 2 & $.244^{b}$ & .060 & .041 & .97921996 & .044 & 4.748 & 1 & 102 & .032 \\
\hline 3 & $.349^{\mathrm{c}}$ & .122 & .096 & .95075416 & .063 & 7.199 & 1 & 101 & .009 \\
\hline
\end{tabular}

Table 4. Model 2 - Internet based technological capability and Collaborative practice with customers as predictors of Quality Performance (Control variable $=$ Company Size)

\begin{tabular}{|c|c|c|c|c|c|c|c|c|c|}
\hline \multirow[b]{2}{*}{ Model } & \multirow[b]{2}{*}{$\mathrm{R}$} & \multirow[b]{2}{*}{ R Square } & \multirow[b]{2}{*}{$\begin{array}{l}\text { Adjusted } \\
\text { R Square }\end{array}$} & \multirow[b]{2}{*}{$\begin{array}{l}\text { Std. Error of } \\
\text { the Estimate }\end{array}$} & \multicolumn{5}{|c|}{ Change Statistics } \\
\hline & & & & & $\begin{array}{l}\text { R Square } \\
\text { Change }\end{array}$ & FChange & df 1 & df2 & Sig. F Change \\
\hline 1 & $.237^{a}$ & .056 & .047 & .97614407 & .056 & 6.145 & 1 & 103 & .015 \\
\hline 2 & $.237^{b}$ & .056 & .038 & .98091372 & .000 & .001 & 1 & 102 & .978 \\
\hline 3 & $.388^{c}$ & .150 & .125 & .93534325 & .094 & 11.181 & 1 & 101 & .001 \\
\hline
\end{tabular}

a. Predictors: (Constant), No. of people employed in Australia

b. Predictors: (Constant), No. of people employed in Australia, Internet based technological capability

c. Predictors: (Constant), No. of people employed in Australia, Inter net based technological capability, Collaborative practice with customers 
collaborative practices with customers. As such, only $\mathrm{H} 2 \mathrm{~b}$ was accepted. Interestingly, the control variable, company size (as measured by number of employees) was found to also have a weak though significant influence on quality performance in the surveyed organizations.

H3a: Vendors' financial performance will benefit from utilizing an Internet based technological capability

H3b: Vendors' financial performance will benefit from utilizing collaborative practices with customers

Model 3 (see Table 5 below) was used to test these hypotheses. The results indicate that neither of the hypotheses is supported. No significant effect on financial performance was recorded for either use of an Internet based technological capability or collaborative practices with customers. As such both $\mathrm{H} 3 \mathrm{a}$ and $\mathrm{H} 3 \mathrm{~b}$ were rejected.

\section{Discussion}

\subsection{General Discussion}

The results of this study provide further evidence supporting the contention that the benefits from collaboration in the supply chain are not as widespread or as clearly identifiable when viewed from the perspective of the vendor. The respondents in this study were operations professionals representing manufacturing firms that could be expected to benefit from either having access to Internet based customer interfaces or from partnering with customers. An important theme in the supply chain management literature is that the manufacturing sector is particularly vulnerable to the problems associated with supply chain dynamics (e.g. the bullwhip effect). Integration with customers at both the technological and process level is held to be an important strategy to mitigate these problems. The results above indicate that in the mind of the vendor collaboration will effect operational performance in areas such a schedule accuracy, inventory control and logistics cost. The effect recorded, however, is weak for both technological capability and collaborative practice. This result is consistent with the contention that closer ties with customers will help mitigate coordination problems in the supply chain, but the weak nature of the effect begs the question as to whether collaboration is powerful enough to be having a meaningful impact on these problems. In other words, the effect is statistically significant, but is it really enough to make a difference?

The results relating to quality performance are more encouraging, with the effect of collaborative practice being both significant and noticeably stronger. Interestingly, in this case technological capability has no significant impact, and the results appear to be modified by company size. These findings indicate that quality of customer service and products can be significantly enhanced by closer partnering with customers, and that vendors have a clearer view of this being the case. From a supply

Table 5. Model 3 - Internet based technological capability and Collaborative practice with customers as predictors of Financial Performance (Control variable $=$ Company Size)

\begin{tabular}{|c|c|c|c|c|c|c|c|c|c|}
\hline \multicolumn{10}{|c|}{ Model Summary } \\
\hline \multirow[b]{2}{*}{ Model } & \multirow[b]{2}{*}{$\mathrm{R}$} & \multirow[b]{2}{*}{ R Square } & \multirow[b]{2}{*}{$\begin{array}{l}\text { Adjusted } \\
\text { R Square }\end{array}$} & \multirow[b]{2}{*}{$\begin{array}{l}\text { Std. Error of } \\
\text { the Estimate }\end{array}$} & \multicolumn{5}{|c|}{ Change Statistics } \\
\hline & & & & & $\begin{array}{l}\text { R Square } \\
\text { Change }\end{array}$ & FChange & df 1 & df2 & Sig. F Change \\
\hline 1 & $.154^{\mathrm{a}}$ & .024 & .014 & .99286025 & .024 & 2.501 & 1 & 103 & .117 \\
\hline 2 & $.158^{\mathrm{b}}$ & .025 & .006 & .99713066 & .001 & .120 & 1 & 102 & .730 \\
\hline 3 & $.185^{\mathrm{c}}$ & .034 & .005 & .99725940 & .009 & .974 & 1 & 101 & .326 \\
\hline \multicolumn{10}{|c|}{ a. Predictors: (Constant), No. of people employed in Australia } \\
\hline \multicolumn{10}{|c|}{ b. Predictors: (Constant), No. of people employed in Australia, Inter net based technological capability } \\
\hline \multicolumn{10}{|c|}{$\begin{array}{l}\text { c. Predictors: (Constant), No. of people employed in Australia, Internet based technological capability, Collaborative practice } \\
\text { with customers }\end{array}$} \\
\hline
\end{tabular}


chain management perspective, however, it also shows that the technological capability being provided by Internet based alternatives to enable collaboration are not seen by vendors to be of importance in enhancing the quality of either their services or products. Rather, they see closer partnering and coordination as being pivotal, not technology.

The final set of hypotheses relates to financial performance, and in this case no significant effect was recorded for either construct. Again, this indicates that from the perspective of manufacturing vendors neither technological capability nor collaborative practice with customers has a direct significant impact on either profit, cash flow or revenue growth within their firm. This result is consistent with those of the European study in the fast moving consumer goods (FMCG) sector in the UK which reported vendors to major supermarket chains being skeptical and apathetic about programs such as "efficient consumer response" (Corsten and Kumar, 2003). The net result of this finding could therefore be interpreted as being that collaboration in the supply chain has a moderate effect on some operational and service related performance outcomes, but that in the mind of the vendor this does not translate into tangible financial benefits. However, this same study (Corsten and Kumar, 2003) also found that there was evidence that suppliers did benefit from collaboration even though they could not readily see these benefits. This study provides some support for this in that a further regression model found that both operational and quality performance were predictors of financial performance (see Table 6 below).

It is also supportive of the findings of an earlier North American study where the effect of supply chain integration on financial performance was found to be mediated by customer service (Vickery et al., 2003). In summary, there is evidence that vendors see some benefits for them in closer collaboration with customers, but that their perception is that the value derived is of marginal importance and limited to operational and service related outcomes. In particular, they see no direct link to financial outcomes. There is evidence, however, that financial outcomes can be linked to improvements in operational and customer service quality performance. The implication is that the real financial benefits of collaboration may exist for vendors, but that they are unable to clearly see them as the direct link is not apparent. As well, the results show that collaborative practice is a stronger determinant of performance for vendors than is technological capability, and that for some areas of performance (e.g. quality) it is not just a stronger determinant, but can be seen to be a primary determinant.

\subsection{Implications for Theory}

The findings of this study indicate that although there is evidence that collaboration with customers at a supply chain level can yield benefits for vendors, these benefits may not be clearly visible for supplier organizations. Taken from a TCE perspective, many vendors find themselves in a position where major customers dictate terms in the supply chain, and as such collaboration with customers is often seen to be mandated by them. In this context many vendors would see collaboration as incurring a set of transaction related costs that they feel are just a condition of maintaining the relationship with the customer. This perception can create the perception

Table 6. Model 4 - Operational Performance and Quality Performance as predictors of Financial Performance

Model Summary

\begin{tabular}{|c|c|c|c|c|c|c|c|c|c|}
\hline \multirow[b]{2}{*}{ Model } & \multirow[b]{2}{*}{$\mathrm{R}$} & \multirow[b]{2}{*}{ R Square } & \multirow[b]{2}{*}{$\begin{array}{l}\text { Adjusted } \\
\text { R Square }\end{array}$} & \multirow[b]{2}{*}{$\begin{array}{l}\text { Std. Error of } \\
\text { the Estimate }\end{array}$} & \multicolumn{5}{|c|}{ Change Statistics } \\
\hline & & & & & $\begin{array}{l}\text { R Square } \\
\text { Change }\end{array}$ & FChange & df 1 & $\mathrm{df2}$ & Sig. F Change \\
\hline 1 & $.454^{\mathrm{a}}$ & .206 & .199 & .89519380 & .206 & 26.777 & 1 & 103 & .000 \\
\hline 2 & $.527^{b}$ & .278 & .264 & .85801617 & .072 & 10.119 & 1 & 102 & .002 \\
\hline
\end{tabular}

a. Predictors: (Constant), Operational performance

b. Predictors: (Constant), Operational performance, Quality perfor mance 
that the costs of collaboration are all being incurred by the vendor for the benefit of the customer. This would be consistent with other research in this area where such perceptions have been recorded (Corsten and Kumar, 2003; Power, 2002; Power, 2005; Power and Simon, 2004). In this type of situation it could also be reasonably expected that levels of trust would be low (particularly for vendors) if the terms of supply chain collaboration were being dictated by customers. With trust at a premium and the costs of collaboration being seen (at least in the eyes of the vendor) to be borne by the vendor both coordination and risk based costs for the vendor would be perceived to be high.

From a KBV of the firm viewpoint these findings could be interpreted as showing that knowledge transfer between firms in the supply chain is most effective when enabled by collaborative practice rather than just technological capability. In this sense the case for the effective transfer of knowledge being more a tacit rather than an explicit process finds some support (Heiman and Nickerson, 2004). Further support for this comes from the evidence indicating that financial benefits may be real but not directly apparent to vendors. In other words, some of the effects of being able to exchange and access knowledge enabled by collaboration may not be readily visible not just as a result of the TCE related issues discussed above, but also because of the tacit nature of the exchange. Support for this lies in the importance of collaborative practice when compared to technological capability. Much of the learning and improvement that comes from collaborative practice would be in the tacit exchanges between humans. The technological capability to connect, on the other hand, could be seen to be at a more superficial, explicit level.

\subsection{Implications for Practice}

The issue of collaboration is a vexed one for many managers faced with on the one hand a need to build relationships with customers, and on the other the need to ensure the costs of knowledge exchange are balanced by benefits for them. The results of this study indicate that vendor performance can be enhanced by collaboration, that some of the benefits may not be readily apparent, and that real partnering and collaborative practice are better sources of leverage than investment in technological solutions alone. This has important implications for management decision making in terms of where and why to invest, as well as what to expect as a reasonable return on this investment. The evidence suggests that the benefits of collaboration can be realized, but that they may not be directly attributable to investments in collaborative processes. In other words, real financial benefits may be realized, but they may not always be directly attributable to collaboration per se. What is more likely is that collaborative practice, combined with technological investment, will improve performance in operations and enable better service for customers. This will lead to better financial performance, but for managers the key insight will be in understanding that the primary effect of collaboration will be in promoting operational excellence through knowledge transfer. The inference is that financial performance of the firm will still be a function of operational excellence based in robust and effective business processes. It is here that collaboration has a direct impact, the financial benefits being an outcome of this interaction.

\section{Conclusion}

The problematic nature of collaboration for vendors is highlighted by this research. The evidence shows that vendors can benefit from collaboration, but that there is an apparent gap between benefits realized and those perceived. It is also shown that in general, collaboration appears to bear more fruit than solely investing in technological solutions. As a provider of goods and services in a supply chain relative power is an important factor in determining strategy. The moderation of the results by firm size provides some evidence suggesting that more powerful vendors may be better placed to collaborate as the balance of power may be in their favor. It could also be inferred that the risks associated with collaboration bear heavily on the minds of vendors, potentially acting to both constrain investment in such strategies and to limit expectations for returns.

\section{Acknowledgements}

The author would like to acknowledge the support of CIPSA in providing access to their membership for the conduct of this study. 


\section{References}

Akkermans, H., Bogerd, P. and van Doremalen, J. (2004). Travail, transparency and trust: A case study of computer-supported collaborative supply chain planning in high-tech electronics European Journal of Operational Research, 153(2), pp.445-456.

Barringer, B. R. and Harrison, J. S. (2000). Walking a tightrope: creating value through interorganizational relationships Journal of Management, 26(3), pp.367-403.

Chen, F., Drezner, Z., Ryan, J. K. and Simchi-Levi, D. (2000a). Quantifying the bullwhip effect in a simple supply chain: The impact of forecasting, lead times, and information Management Science, 46(3), pp.436-443.

Chen, F., Ryan, J. K. and Simchi-Levi, D. (2000b). The impact of exponential smoothing forecasts on the bullwhip effect Naval Research Logistics, 47(4), pp.269-286.

Corsten, D. and Kumar, N. (2003) Profits in the pie of the beholder Harvard Business Review, 81,5, pp.22.

Dejonckheere, J., Disney, S. M., Lambrecht, M. R. and Towill, D. R. (2003). Measuring and avoiding the bullwhip effect: A control theoretic approach European Journal of Operational Research, 147(3), pp.567-590.

Disney, S. M. and Towill, D. R. (2003). The effect of vendor managed inventory (VMI) dynamics on the Bullwhip Effect in supply chains International Journal of Production Economics, 85(2), pp.199-215.

Djonckheere, J., Disney, S. M., Lambrecht, M. R. and Towill, D. R. (2003). Measuring and avoiding the bullwhip effect: A control theoretic approach European Journal of Operational Research, 147(3), pp.567-590.

Djonckheere, J., Disney, S. M., Lambrecht, M. R. and Towill, D. R. (2004). The impact of information enrichment on the bullwhip effect in supply chains: A control engineering perspective European Journal of Operational Research, 153(3), pp.727-750.

Dyer, J. H., Cho, D. S. and Chu, W. J. (1998). Strategic Supplier Segmentation: The next best practice in supply chain management California Management Review, 40(2), pp.57-77.

Dyer, J. H. and Singh, H. (1998). The relational view: Cooperative strategy and sources of interorganizational competitive advantage Academy of Management Review, 23(4), pp.660-679.

Fearne, A., Barrow, S. and Schulenberg, D. (2006). Implanting the benefits of buyer-supplier collaboration in the soft fruit sector Supply Chain Management, 11(1), pp.3-6.

Fernie, J. (1995). International comparisons of supply chain management in grocery retailing Service Industries Journal, 15(4), pp.134-147.

Fisher, L. M. (1996). How strategic alliances work in biotech Strategy and Business,1, pp.1-7.

Forrester, J. (1958). Industrial dynamics, a major breakthrough for decision makers Harvard Business Review, 36(4), pp.37-66.
Forrester, J. W. (1961). Industrial Dynamics, MIT Press, Cambridge, MA.

Grant, R. M. (1997). The knowledge-based view of the firm: Implications for management practice Long Range Planning, 30(3), pp.450-454.

Grant, R. M. and Baden-Fuller, C. (1995). A knowledge-based theory of inter-firm collaboration Academy of Management Proceedings, pp.17-21.

Grant, R. M. and Baden-Fuller, C. (2004). A Knowledge Assessing Theory of Strategic Alliances The Journal of Management Studies, 41(1), pp.61-84.

Gulati, R. (1995). Does familiarity breed trust? The implications of repeated ties for contractual choice in alliances The Academy of Management Journal, 38(1), pp.85-112.

Harbison, J. R. and Pekar, P. (1998). Smart Alliances, JosseyBass, San Francisco.

Hart, P. and Saunders, C. (1997). Power and trust: Critical factors in the adoption and use of electronic data interchange Organization Science, 8(1), pp.23-42.

Heiman, B. and Nickerson, J. A. (2002). Towards reconciling transaction cost economics and the knowledge-based view of the firm: The context of interfirm collaborations International Journal of the Economics of Business, 9(1), pp.97.

Heiman, B. A. and Nickerson, J. A. (2004). Empirical evidence regarding the tension between knowledge sharing and knowledge expropriation in collaborations Managerial and Decision Economics, 25(6-7), pp.401.

Holweg, M., Disney, S. M., Holmstrom, J. and Smaros, J. (2005). Supply chain collaboration: Making sense of the strategy continuum European Management Journal, 23(2), pp.170-181.

Jarillo, J. C. (1988). On strategic networks Strategic Management Journal, 9(1), pp.31-41.

Johnston, D. A., McCutcheon, D. M., Stuart, F. I. and Kerwood, H. (2004) Effects of supplier trust on performance of cooperative supplier relationships Journal of Operations Management, 22(1), pp.23-38.

Kersten, W., Schroeder, K. A. and Schulte-Bisping, A. (2004). Internet supported sourcing of complex material Business Process Management Journal, 10(1), pp.101-114.

Kleist, V. F. (2004). A Transaction Cost Model of Electronic Trust: Transactional Return, Incentives for Network Security and Optimal Risk in the Digital Economy Electronic Commerce Research, 4(1-2), pp.41.

Kulp, S. C., Lee, H. L. and Ofek, E. (2004). Manufacturer benefits from information integration with retail customers Management Science, 50(4), pp.431-444.

Kwon, I.-W. and Suh, T. (2004). Factors affecting the level of trust and commitment in Supply Chain relationships Journal of Supply Chain Management, 40(2), pp.4-14.

Landry, J. T. (1998). Supply chain management - The value of trust Harvard Business Review, 76, January/February, pp.18-19. 
Lee, H. G. and Clark, T. L. (1999). Business value of Electronic Data Interchange: The critical role of organisational process innovations, In Proceedings of the 5th International Conference of the Decision Sciences Institute(Eds, Despotis, D. K. and Zopounidis, C.) New Technologies Publications, Athens, Greece, pp. 358-360

Lee, H. L. and Billington, C. (1995). The evolution of supply chain models and practice at Hewlett Packard Interfaces, 25(5), pp.42-63.

Lee, H. L., Padmanabhan, V. and Whang, S. J. (1997a). The bullwhip effect in supply chains Sloan Management Review, 38(3), pp.93-102.

Lee, H. L., Padmanabhan, V. and Whang, S. J. (1997b). Information distortion in a supply chain: The bullwhip effect Management Science, 43(4), pp.546-558.

Lee, H. L. and Whang, S. (2000). Information sharing in a supply chain International Journal of Technology Management, 20(3/4), pp.373-387.

Metters, O. (1997). Quantifying the bullwhip effect in supply chains Journal of Operations Management, 15(2), pp.89100.

Monczka, R. M., Petersen, K. J., Handfield, R. B. and Ragatz, G. L. (1998). Success factors in strategic supplier alliances: The buying company perspective Decision Sciences, 29(3), pp.553-577.

Mouritsen, J. and Thrane, S. (2006). Accounting, network complementarities and the development of interorganisational relations Accounting, Organizations and Society, 31(3), pp.241.

New, S. J. and Burnes, B. (1998). Developing effective customer-supplier relationships: more than one way to skin a cat The International Journal of Quality and Reliability Management, 15(4), pp.377.

Oliver, C. (1990). Determinants of interorganizational relationships: Integration and future directions Academy of Management Review, 15, pp.241-265.

Powell, W. W. (1990). Neither marke nor hierarchy: network forms of organization Research in Organizational Behaviour, 12, pp.295-336.

Power, D. J. (2002). Application of Established and Emerging B2B E-Commerce Technologies: Australian Empirical Evidence Integrated Manufacturing Systems, 13(8), pp.573-585.

Power, D. J. (2005). Implementation and Use of B2B Enabling Technologies: Five Manufacturing Case Studies Journal of Manufacturing Technology Management, 16(6), pp.554572.

Power, D. J. and Simon, A. (2004). Adoption and diffusion in technology implementation: a supply chain study International Journal of Operations and Production Management, 24(6), pp.566-587.

Power, D.J. and Singh, P.J. (2007). The E-integration dilemma: the linkages between Internet technology application, trading partner relationships and structural change Journal of Operations Management, 25(6), pp.12921310.
Scott, J. (1987). Organizations, Simon and Schuster, Englewood Cliffs, N.J.

Simatupang, T. M., Wright, A. C. and Sridharan, R. (2004). Applying the theory of constraints to supply chain collaboration Supply Chain Management, 9(1), pp.57-70.

Spekman, R. E. and Carraway, R. (2006). Making the transition to collaborative buyer-seller relationships: An emerging framework Industrial Marketing Management, 35(1), pp.10.

Stephen, A. T. and Coote, L. V. (2005). Towards an Understanding of the Governance of Complex Networks of Relationships: Uncertainty, Governance System Choices, and Performance Outcomes American Marketing Association. Conference Proceedings, 16, pp.112.

Sterman, J. (1989). Modelling managerial behaviour: Misperception of feedback in a dynamic decision making environment Management Science, 35(3), pp.321-339.

Stuart, F. I. (1997). Supplier alliance success and failure - a longitudinal dyadic perspective International Journal of Operations E Production Management, 17(5-6), pp.539557.

Thorelli, H. B. (1986). Networks: Between markets and hierarchies Strategic Management Journal, 7, pp.37-51.

van Donk, D. P. and van der Vaart, T. (2005). A case of shared resources, uncertainty and supply chain integration in the process industry International Journal of Production Economics, 96(1), pp.97-108.

Vereecke, A. and Muylle, S. (2006). Performance improvement through supply chain collaboration in Europe International Journal of Operations $\mathcal{E}$ Production Management, 26(11), pp.1176-1198.

Vickery, S. K., Jayaram, J., Droge, C. and Calantone, R. (2003). The effects of an integrative supply chain strategy on customer service and financial performance: an analysis of direct versus indirect relationships Journal of Operations Management, 21(5), pp.523-539.

Voeth, M. and Herbst, U. (2006). Supply chain pricing: A new perspective on pricing in industrial markets Industrial Marketing Management, 35(1), pp.83.

Williamson, O. E. (1975). Markets and hierarchies:Analysis and antitrust implications, Free Press, New York.

Williamson, O. E. (1985). The economic institution of capitalism, Free Press, New York.

Williamson, O. E. (1991). Comparative Economic Organization: The Analysis of Discrete Structural Alternatives Administrative Science Quarterly, 36(2), pp.269-296.

Wuyts, S. and Geyskens, I. (2005). The Formation of BuyerSupplier Relationships: Detailed Contract Drafting and Close Partner Selection Journal of Marketing, 69(4), pp.103.

Zajac, E. J. and Olsen, C. (1993). From transaction cost to transaction value analysis: implications for the study of interorganizational strategies Journal of Management Studies, 30, pp.130-146. 
Damien Power is Associate Professor of Operations Management at the University of Melbourne, Australia. He has research interests covering supply chain management, e-Commerce and use of information technologies, process re-engineering and management of the extended enterprise. Damien has extensive management experience in industries as diverse as food, electronics and metering technology, and has published over 60 journal articles and conference papers in the area of operations and supply chain management. 